Vol. 3, No. 2, 2016

UDC 339.5:330.23

A. Kisiołek

Wielkopolska Higher School of Social Sciences and Economics in Środa Wielkopolska (Poland)

\title{
THE CONDITION OF THE POLISH RESIDENTIAL HOUSING MARKET IN 2015-2016
}

\begin{abstract}
The building sector is one of the key sectors of the national economy. The article presents a general condition of the residential building market in Poland. In the course of the discussion it is emphasised that the sector depends on the absorption of the EU funds as well as the direction set out by the concept of sustainable building. Among other things, the article also provides the data regarding the development of residential housing in the specific voivodeships, the number of building permits issued and the (PMR) Construction Climate Index. Finally, the influence of the building sector on the development of the Polish economy is explicitly marked.

Keywords: building market, economic situation of the building sector, construction-assembly production, residential housing, developer market.
\end{abstract}

\section{Formulation of the problem}

The building sector is experiencing changes related to the problem of competitiveness (unstable market, unpredictable future economic situation), the implementation of modern, "sustainable" technology as well as the need to ensure the quality of the building objects at all stages, i.e., design, construction and exploitation.

The building market in Poland, including the residential housing sector, is one of the key sectors of the domestic economy and, as such, is often used as a yardstick to measure against in the discussions regarding its present conditions and prospects for development. The dynamics of this sector is strictly contingent upon the absorption of EU funds as well as the most recent trends related to the implementation of the concept of sustainable development present in all EU member states. Therefore, an analysis of its condition is crucial not only for economists, but also engineers, in both the micro- and macroeconomic aspect.

\section{Analysis of recent research and publications}

The condition of the building market is frequently discussed in the academic literature. At the same time, the building industry, considered a macroeconomic spinning wheel for the Polish economy, is often taken as a litmus test for the analysis of its economic condition in general. Scientific reports focus predominantly on the trends and directions of development of sustainable building, which, according to L. Czarnecki and M. Kapron, constitutes "the building industry of the future" [1, p. 72-73]. The issue is also discussed by Z. Paszkowski [2, p. 194], M. Piasecki [3, p. 34], or A. Pabian, the author of an interesting concept of sustainable building process $[4$, p. 50$]$.

Problems relating to the economic condition of the Polish building sector, specifically, residential housing, although seemingly less popular, are discussed, among others, in "Materiały Budowlane", (a monthly journal, articles by M. Kowalska or J. Koblyarz), or "Inżynier Budownictwa" (published by the Polish Chamber of Building Engineers, articles by M. Wielgo).

The purpose of the article is to carry out a consolidated analysis of the economic condition of the residential building sector in Poland in the period 2015-2016.

\section{Presentation of the main material}

According to the statistics of the Main Statistical Office, in 2015140.710 flats were commissioned, which is $3.2 \%$ more than in 2014 . However, the ostensible growth is a consequence of the falls experienced in the two previous years, compared to the results obtained in 2012. In order to have a more objective picture, one should consider the fact that in 2014 143, 2 thousand flats were commissioned, which is $1.4 \%$ less than in 2013 (145.1 thousand) which, in turn constitutes a fall by $5.1 \%$ compared with 2012 [5, p. 66]. The detailed statistics are provided in Table 1.

The forecast for 2016 looks optimistic, as the number of flats under construction is 


\section{A. Kisiotek}

168,4 thousand, i.e., $14 \%$ more than in 2015 [5, p. 66]. However, this single fact does not constitute a sufficient basis for any predictions concerning the future economic condition. Crucially, it is the building permits issued in a given period that should be considered the most telling indicator, as they underlie future investments. The analysis of the relevant data in this respect will be presented here in the course of the chapter.

Residential housing in period Jan. - Dec. 2015 in selected voivodeships

\begin{tabular}{|c|c|c|c|c|c|c|}
\hline \multirow[b]{2}{*}{ Voivodeship } & \multicolumn{2}{|c|}{ Flats } & \multicolumn{2}{|c|}{ Usable space } & \multirow{2}{*}{$\begin{array}{c}\text { Average usable } \\
\text { space of flat } \\
{\left[\mathrm{m}^{2}\right]}\end{array}$} & \multirow{2}{*}{$\begin{array}{l}\text { Number of } \\
\text { flats under } \\
\text { construction }\end{array}$} \\
\hline & $\begin{array}{c}\text { absolute } \\
\text { values }\end{array}$ & $\begin{array}{l}I-X I I \\
2014= \\
=100\end{array}$ & {$\left[\mathrm{~m}^{2}\right]$} & $\begin{array}{l}I-X I I \\
2014== \\
100\end{array}$ & & \\
\hline 1 & 2 & 3 & 4 & 5 & 6 & 7 \\
\hline \multicolumn{7}{|c|}{ Total (level A) } \\
\hline POLAND & 147710 & 103.2 & 14797089 & 102.5 & 100.2 & 168403 \\
\hline dolnośląskie & 13959 & 100.0 & 1243300 & 99.0 & 89.1 & 16860 \\
\hline kujawsko-pomorskie & 6715 & 107.5 & 669114 & 106.9 & 99.6 & 6631 \\
\hline lubelskie & 6248 & 109.7 & 659020 & 105.5 & 105.5 & 7653 \\
\hline lubuskie & 3230 & 96.3 & 312394 & 100.5 & 96.7 & 4000 \\
\hline łódzkie & 7167 & 110.2 & 815622 & 10.6 & 113.8 & 7498 \\
\hline małopolskie & 14723 & 94.2 & 1572593 & 98.6 & 106.8 & 19373 \\
\hline mazowieckie & 29095 & 94.9 & 2664364 & 94.9 & 91.6 & 34964 \\
\hline opolskie & 1731 & 89.5 & 224523 & 92.1 & 129.7 & 1613 \\
\hline podkarpackie & 7645 & 118.8 & 830814 & 110.7 & 108.7 & 7159 \\
\hline podlaskie & 4772 & 113.7 & 481082 & 108.1 & 100.8 & 4746 \\
\hline pomorskie & 13123 & 120.5 & 1140337 & 111.6 & 86.9 & 13925 \\
\hline Śląskie & 10138 & 104.0 & 1219811 & 103.5 & 120.3 & 11066 \\
\hline świętokrzyskie & 3355 & 95.0 & 373854 & 102.9 & 111.4 & 3168 \\
\hline warmińsko-mazurskie & 4351 & 100.6 & 417884 & 100.8 & 96.0 & 4300 \\
\hline wielkopolskie & 16168 & 110.5 & 1661073 & 109.9 & 102.7 & 18715 \\
\hline zachodniopomorskie & 5290 & 97.7 & 511304 & 98.5 & 96.7 & 6732 \\
\hline \multicolumn{7}{|c|}{ Individual housing (level B) } \\
\hline POLSKA & 79731 & 104.7 & 10815836 & 103.0 & 135.7 & 78855 \\
\hline dolnośląskie & 5762 & 101.1 & 760097 & 98.6 & 131.9 & 5404 \\
\hline kujawsko-pomorskie & 3986 & 105.0 & 16200 & 104.5 & 129.5 & 3595 \\
\hline lubelskie & 4407 & 104.2 & 553624 & 102.1 & 125.6 & 4406 \\
\hline lubuskie & 1814 & 103.2 & 231587 & 104.0 & 127.7 & 1711 \\
\hline łódzkie & 4917 & 104.3 & 666851 & 101.0 & 135.6 & 4933 \\
\hline małopolskie & 8385 & 98.9 & 1212353 & 100.9 & 144.6 & 8626 \\
\hline mazowieckie & 11975 & 106.2 & 1647596 & 100.6 & 137.6 & 10717 \\
\hline
\end{tabular}


The Condition of the Polish Residential Housing Market in 2015-2016

Continuation of table 1

\begin{tabular}{|c|c|c|c|c|c|c|}
\hline 1 & 2 & 3 & 4 & 5 & 6 & 7 \\
\hline opolskie & 1400 & 99.2 & 203737 & 96.3 & 145.5 & 1292 \\
\hline podkarpackie & 5373 & 107.1 & 706148 & 105.4 & 131.4 & 5066 \\
\hline podlaskie & 2139 & 99.7 & 335642 & 101.1 & 156.9 & 2281 \\
\hline pomorskie & 5083 & 106.7 & 694835 & 104.6 & 136.7 & 5438 \\
\hline śląskie & 7282 & 106.5 & 1036793 & 105.7 & 142.4 & 7675 \\
\hline świętokrzyskie & 2454 & 102.9 & 323994 & 106.5 & 132.0 & 2495 \\
\hline warmińsko-mazurskie & 2302 & 98.2 & 304373 & 99.1 & 132.2 & 2289 \\
\hline wielkopolskie & 9355 & 113.6 & 1238093 & 110.8 & 132.3 & 9496 \\
\hline zachodniopomorskie & 3097 & 101.8 & 383913 & 99.1 & 124.0 & 3431 \\
\hline \multicolumn{7}{|c|}{ Cooperative housing (level C) } \\
\hline POLAND & 2052 & 58.8 & 115876 & 58.2 & 56.5 & 1285 \\
\hline dolnośląskie & 60 & 56.1 & 5073 & 82.8 & 84.6 & 136 \\
\hline kujawsko-pomorskie & - & - & - & - & - & - \\
\hline lubelskie & 108 & 46.6 & 5924 & 48.4 & 54.9 & 299 \\
\hline lubuskie & 131 & 72.0 & 6399 & 65.4 & 48.8 & 123 \\
\hline łódzkie & 91 & 69.5 & 6451 & 95.5 & 70.9 & 113 \\
\hline małopolskie & - & - & - & - & - & 25 \\
\hline mazowieckie & 528 & 39.3 & 30181 & 35.9 & 57.2 & 70 \\
\hline opolskie & - & - & - & - & - & - \\
\hline podkarpackie & 375 & 69.8 & 20445 & 68.5 & 54.5 & 249 \\
\hline podlaskie & 69 & - & 3367 & - & 48.8 & - \\
\hline pomorskie & 225 & 88.9 & 12303 & 94.1 & 54.7 & - \\
\hline śląskie & 80 & 333.3 & 5474 & 416.6 & 68.4 & 57 \\
\hline świętokrzyskie & 39 & 8.5 & 2076 & 8.7 & 53.2 & 50 \\
\hline warmińsko-mazurskie & 156 & 421.6 & 7501 & 489.6 & 48.1 & - \\
\hline wielkopolskie & 72 & 66.7 & 3812 & 63.9 & 52.9 & 36 \\
\hline zachodniopomorskie & 118 & 157.3 & 6870 & 149.5 & 58.2 & 127 \\
\hline \multicolumn{7}{|c|}{ Premises for sale or lease (level D) } \\
\hline POLAND & 62448 & 105.7 & 3702108 & 105.2 & 59.3 & 86498 \\
\hline dolnośląskie & 8022 & 109.8 & 473114 & 108.0 & 59.0 & 10810 \\
\hline kujawsko-pomorskie & 2201 & 103.7 & 126547 & 107.5 & 57.5 & 2874 \\
\hline lubelskie & 476 & 132.5 & 88937 & 137.3 & 60.3 & 2808 \\
\hline lubuskie & 1201 & 98.6 & 69602 & 104.3 & 58.0 & 2131 \\
\hline łódzkie & 1980 & 138.3 & 133211 & 154.7 & 67.3 & 2349 \\
\hline małopolskie & 6185 & 87.3 & 354694 & 90.6 & 57.3 & 10645 \\
\hline
\end{tabular}


End of table 1

\begin{tabular}{|c|c|c|c|c|c|c|}
\hline 1 & 2 & 3 & 4 & 5 & 6 & 7 \\
\hline mazowieckie & 16163 & 94.2 & 966722 & 92.8 & 59.8 & 24082 \\
\hline opolskie & 327 & 85.4 & 20626 & 87.8 & 63.1 & 321 \\
\hline podkarpackie & 1729 & 219.4 & 95410 & 208.4 & 55.2 & 1818 \\
\hline podlaskie & 2460 & 127.6 & 137421 & 127.5 & 55.9 & 2438 \\
\hline pomorskie & 7408 & 133.3 & 415613 & 126.1 & 56.1 & 8281 \\
\hline śląskie & 2558 & 96.9 & 168503 & 90.5 & 65.9 & 3210 \\
\hline świętokrzyskie & 742 & 143.5 & 42713 & 156.4 & 57.6 & 615 \\
\hline warmińsko-mazurskie & 1815 & 101.7 & 100683 & 102.4 & 55.5 & 1966 \\
\hline wielkopolskie & 6423 & 106.7 & 404913 & 108.0 & 63.0 & 9025 \\
\hline zachodniopomorskie & 1758 & 87.5 & 103399 & 90.7 & 58.8 & 3125 \\
\hline
\end{tabular}

Source: [5, p. 66-67]

The analysis of the data provided in Table 1 leads to interesting conclusions with respect to the "regionalisation" of the economic condition concerning the main categories, i.e., individual building, cooperative building, as well as construction of objects for sale or lease.

The analysis of Level A based on the aggregate numbers of commissioned flats in 2015 reveals that the leading building regions in Poland are the following voivodeships: mazowieckie (over 29 thousand commissioned flats), wielkopolskie (over 16 thousand commissioned flats), małopolskie (14.7 thousand commissioned flats) and ślaskie (10.1 thousand commissioned flats). It is possible to observe significant disproportions between the specific regions, e.g., the three voivodeships with the smallest number of commissioned flats, significantly below the results obtained by the abovementioned ones, are lubuskie (3.2 commissioned flats), świętokrzyskie (3.3 thousand commissioned flats) and warmińsko-mazurskie (4.3 commissioned flats). The smallest real number of commissioned flats was noted in opolskie (1.7 thousand), yet, given the size of the voivodeship, the results are hardly comparable to the biggest ones.

In terms of market dynamics at Level A (Table 1) - general statistics, voivodeships pomorskie $(20.5 \%)$, podkarpackie $(18.8 \%)$ and podlaskie $(13.7 \%)$ fared the best.

As for Level B (Table 1) - individual building sector, the leading regions were mazowieckie (11.9 thousand commissioned flats), wielkopolskie ( 9.3 thousand commissioned flats) and małopolskie (8.3 thousand commissioned flats), with the dynamics exceeding the level of $13 \%$ noted in wielkopolskie. In turn, at Level D - building for sale and lease (dominated by developers) mazowieckie (16.1 thousand commissioned flats), dolnośląskie (8 thousand commissioned flats) and pomorskie (7.4 commissioned flats) took the lead. At this point, it should be observed that in terms of market dynamics, the most noticeable stimulation was noted in podkarpackie $(119.4 \%$ growth with respect to 2014), świętokrzyskie (43.5\% growth), lódzkie (38.3\% growth), pomorskie (33.3\% growth) and lubelskie (32.5\% growth). Leading regions aside, the data seem to suggest that the most significant agitation was felt in the developers' sector. A conclusion along these lines may also be drawn given the so-called low-base effect.

The structure of the market in 2015 considering the main forms of residential housing is presented in Table 2. Its major segments are individual housing (54\%) and building for sale and lease $(42 \%)$. The share of other forms noted and registered by the Main Statistical Office, i.e., cooperative building, public building society construction, municipal building or workplacerelated building is marginal $(1.4 \%, 0.9 \%, 1.2 \%$, $0.3 \%$, respectively). 
Number of commissioned flats in period Jan. - Dec. 2015

\begin{tabular}{|l|c|c|c|c|}
\hline \multirow{2}{*}{$\begin{array}{c}\text { Forms of residential } \\
\text { housing }\end{array}$} & \multicolumn{4}{c|}{ Jan. - Dec. 2015 r. } \\
\cline { 2 - 5 } Total & Absolute values & Structure [\%] & Jan.-Dec. 2014=100 & Average flat space $\left[\mathrm{m}^{2}\right]$ \\
\hline Individual & $\mathbf{1 4 7} \mathbf{7 1 0}$ & $\mathbf{1 0 0 . 0}$ & $\mathbf{1 0 3 . 2}$ & $\mathbf{1 0 0 . 2}$ \\
\hline For sale or lease & 79731 & 54.0 & 104.7 & 135.7 \\
\hline Cooperative & 62448 & 42.2 & 105.7 & 59.3 \\
\hline Building society & 2052 & 1.4 & 58.8 & 56.5 \\
\hline Municipal & 1300 & 0.9 & 75.8 & 49.2 \\
\hline Workplace-related & 1735 & 1.2 & 79.7 & 40.5 \\
\hline
\end{tabular}

Source: [5, p. 68]

The statistical data concerning the issuance of building permits constitute one of the key factors in the analysis of the current condition of the entire construction market (not only the residential housing sector). According to the statistics of the Main Office of Building Supervision (GUNB), 183.766 building permits for the construction of 209.687 objects were issued in 2015, which constitutes a decrease by almost $4.9 \%$ in comparison to 2014 and indicates a negative, downward trend in the period from 2010 to 2015 [6, p. 136]. The detailed statistics presented in diagram 1 look far from impressive and call for a thorough analysis of the present situation and prospects for the future of the construction market. In the period under consideration, the biggest number of permits was noted in 2011 (221.033, i.e., over $20 \%$ more than in 2015) [6, p. 136]. The fall is significant and cannot be explained away by using simple arguments, such as amendments to the construction law allowing some investors to operate on the basis of notification and not solely upon building permits (which formerly used to be the case).

On 28 June 2015, revised regulations of the Act of 7 July 1994 - Construction Law (Official Journal of Laws 2013, item 1409, as amended) took effect. As reported in the Factsheet of the Main Statistical Office of Building Supervision, pursuant to article 29 paragraph 1 points $1 \mathrm{a}, 2 \mathrm{~b}$ and $19 \mathrm{a}$, ,detached singlefamily buildings whose impact zone is limited to the plot or plots on which they were designed, detached one-storey transformer station or container transformer station buildings with the space up to $35 \mathrm{~m}^{2}$, as well as water supply, sewage, heating, telecommunications and electrical energy (rated voltage max. $1 \mathrm{kV}$ ) networks may be constructed on the basis of notification" [6, p. 136].
Yet, in the second half of 2015, the number of single-family building construction notifications was only 4.868, which does not make up for the negative image of the statistics presented. At this point, it should be noted that the legislator expected the number of permits to reach approximately 30.000 annually [4].

A significant number of the abovementioned building permits, i.e., the total of 78.994 in 2015 , concerns residential buildings, which allowed preserving a minimal increase tendency for the period 2014-2015, reaching the level of $3.3 \%$ and $1.8 \%$, respectively.

In turn, in 2015 more building permits for the construction of multi-family residential buildings were issued compared with the period of 2010-2015, the number being 3,936. Detailed information concerning the number of building permits for the construction of single- and multifamily residential buildings issued in the period of 2010-2015 is provided in Diagram 2.

The statistics regarding the multi-family residential buildings plausibly indicate not only the market dynamics, but also a specific shift in consumer trends from the construction of traditional, single-family buildings in the economic system towards the purchase of apartments on the developer market. This section of the market has experienced record growth in recent years. According to the information collected by Dziennik Gazeta Prawna, in 2015 developers in Poland started the construction of 86,500 flats, compared with 2014 - 69.700 and 2013 - 51.300. The progress is thus noticeable, and the statistics indicate an unprecedented growth, which is why the market has seen the stabilization of offer prices 


\section{A. Kisiotek}

accompanied simultaneously with the growth of transaction prices. Based on the data provided by Narodowy Bank Polski, M. Kwiatkowska reports that an average transaction price in the 2 nd quarter of 2016 increased by $1.6 \%$ compared with the analogous period of 2015 , which, given the unchanged offer price levels, served to decrease the difference between offer and transaction prices to $3.7 \%$ in mid-2016 (the analogous difference in 2015 was $5.2 \%$ )
According to the author of the quoted text, offer prices stabilized due to a significant number of flats, while the level of transaction prices depends on the growing production costs as well as the fact that the developers include finishing works in their offer to meet their clients' expectations [8, A13]. The number of flats, which the developers started to build in between January - June, January - December 2010-2016, is presented in Diagram 3.

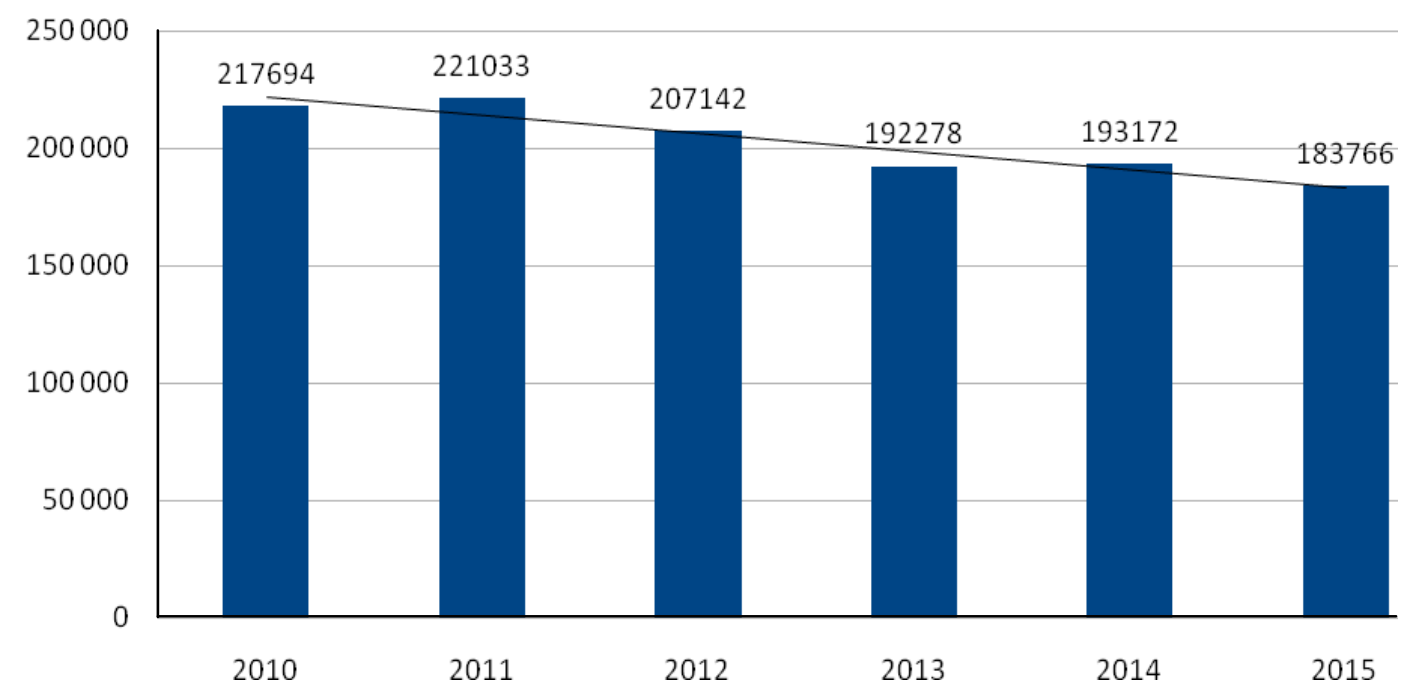

Diagram 1. Building permits issued in 2010-2015

Source: [6, p. 136]

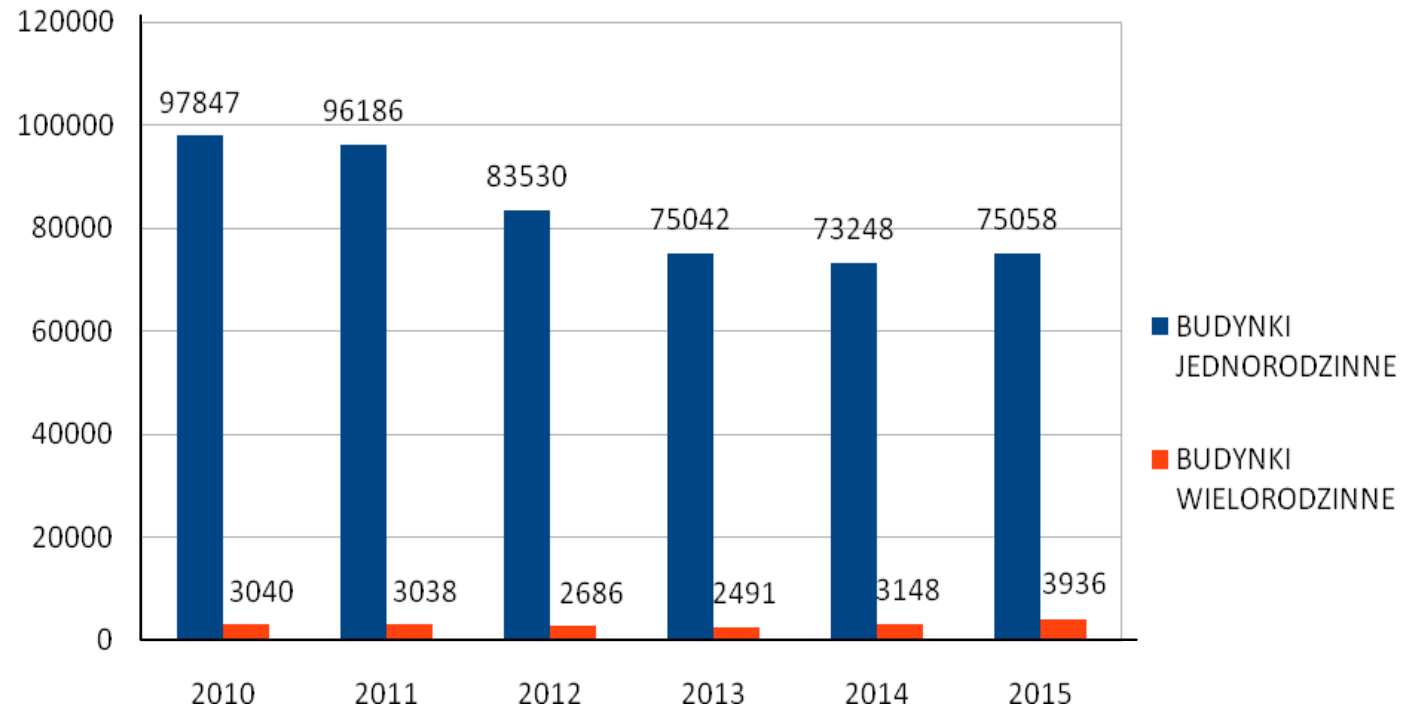

Diagram 2. Number of building permits for the construction of singleand multi-family residential buildings issued in the period of 2010-2015.

Source: [6, p. 136] 


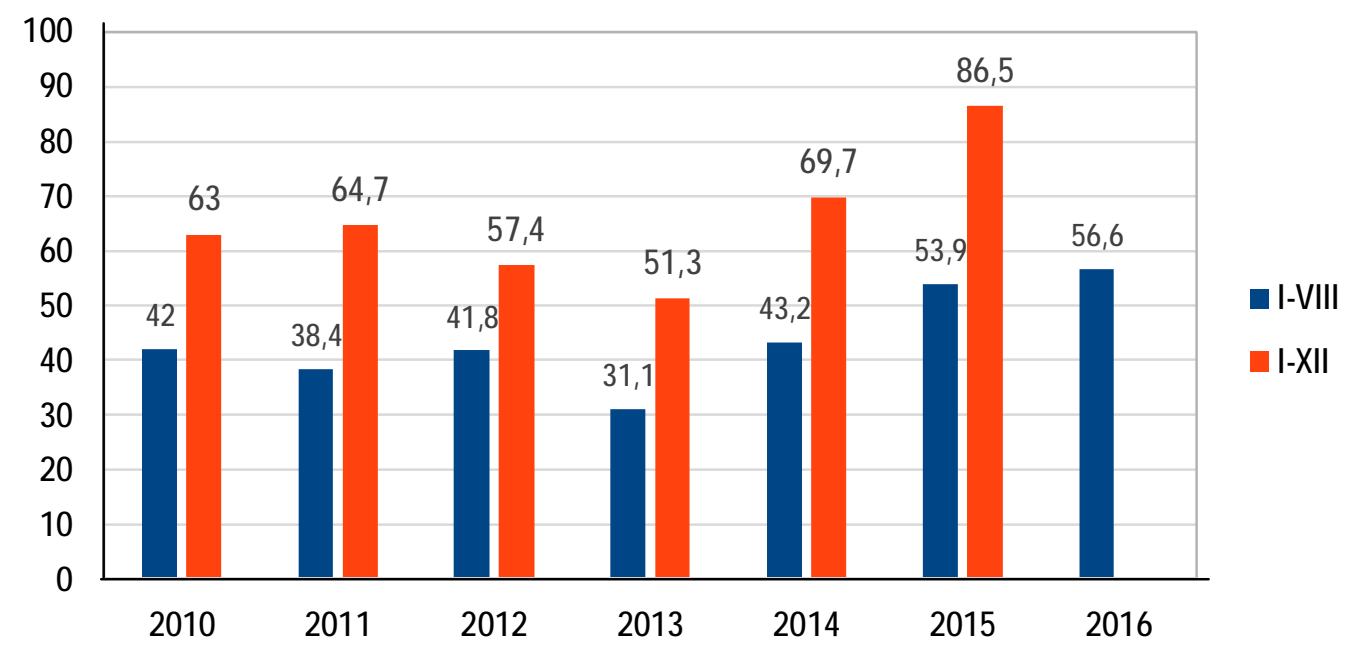

Diagram 3. Flats under construction in 2010 - 2016 (in thousands)

Source: $[8, p . A 13]$

Despite relatively good economic conditions characterizing the first half of 2016 (economic growth, low interest rates, i.e. cheap credits, the approval of the EU budget till 2020) [8, A13], the overall assessment of the market dynamics gives rise to concern, especially when the current situation and the nearest future are taken into consideration. The analysis of the trends over the period of a few years as well as the image of political instability in the international arena force rather conservative forecasts for the future of the construction market and put the current statistics in the center of attention. According to the statistics of the Main Statistical Office for the period of January September 2016, the sale of building - assembly production (measured in fixed prices) of enterprises with more than 9 employees decreased by $14.9 \%$.
This seems to be the continuation of the annual trend, as the downward tendency was noted in both the 1 st and the 2nd quarter of $2016(13.3 \%$ and $11.9 \%$, respectively). Decreased dynamics was noted in all sectors of the building industry, the most severe fall experienced in civil engineering $(18.9 \%)$, resulting directly from delays in the organization of procurement procedures for these investments. A conspicuous decrease also affected companies rendering specialist construction services $(14.3 \%)$ as well as those that specialize in the construction of buildings $(11.3 \%)$. Here, companies specializing in the erection of residential and non-residential buildings, the most numerous group in the sector, suffered the most $(9.7 \%)$ [9, p. 163]. The detailed statistics are presented in Table 3.

Table 3

Sales dynamics of building-assembly production in enterprises with more than 9 employees in the period from January to September 2016 (measured in fixed prices)

\begin{tabular}{|c|c|c|c|c|c|c|c|c|}
\hline \multirow{3}{*}{ Details } & \multicolumn{4}{|c|}{2015} & \multicolumn{4}{|c|}{2016} \\
\hline & I-III & $\mathbf{I}-\mathbf{V I}$ & $\mathbf{I}-\mathbf{I X}$ & IX & I-III & $\mathbf{I}-\mathbf{V I}$ & $\mathbf{I}-\mathbf{I X}$ & IX \\
\hline & \multicolumn{8}{|c|}{ analogous period in the preceding year $=100$} \\
\hline Total: & 103.5 & 101.0 & 102.0 & 97.5 & 86.7 & 88.1 & 85.1 & 84.7 \\
\hline $\begin{array}{l}\text { Including: } \\
\text { investment construction works }\end{array}$ & 98.8 & 98.6 & 99.2 & 94.2 & 87.4 & 88.4 & 85.1 & 85.6 \\
\hline repair / renovation works & 113.6 & 105.7 & 107.3 & 103.5 & 85.5 & 87.6 & 85.1 & 83.1 \\
\hline $\begin{array}{l}\text { Sections: } \\
\text { construction of buildings }\end{array}$ & 99.6 & 99.7 & 102.1 & 92.0 & 91.4 & 92.3 & 88.7 & 91.4 \\
\hline construction of civil engineering facilities & 108.5 & 102.2 & 100.9 & 99.7 & 79.3 & 83.0 & 81.1 & 77.5 \\
\hline specialist building works & 103.8 & 101.3 & 103.4 & 100.8 & 88.4 & 88.8 & 85.7 & 88.9 \\
\hline
\end{tabular}

Source: [9, p. 163] 


\section{A. Kisiotek}

The data presented are unequivocally negative. According to B. Tomczak (Market Research and Analysis Center), in 2016 the volume of investments turned out to be most disappointing, since it is investments, not consumption, that guarantee constant GDP growth. According to the Market Research and Analysis Center, investments fell by $1.8 \%$ in the 1 st quarter and $4.9 \%$ in the 2 nd quarter of 2016 as a consequence of delays in public procurement, which is financed from the EU new budget perspective for 2014-2020. Market analysts consider the decrease to be indicative of the fact that the Polish economy heavily depends on the EU funds [10, p. 64].

While considering the current condition of the building sector, it is interesting to analyse the so-called Construction Climate Index, run for years by PMR. In order to compile a report entitled "The building sector in Poland $2^{\text {nd }}$ half of 2016. Analysis and forecasts for years 2016-2021", a sample of 200 biggest Polish construction companies (specialist managerial and operational level) were surveyed. The results of the survey are presented in Diagram 4.

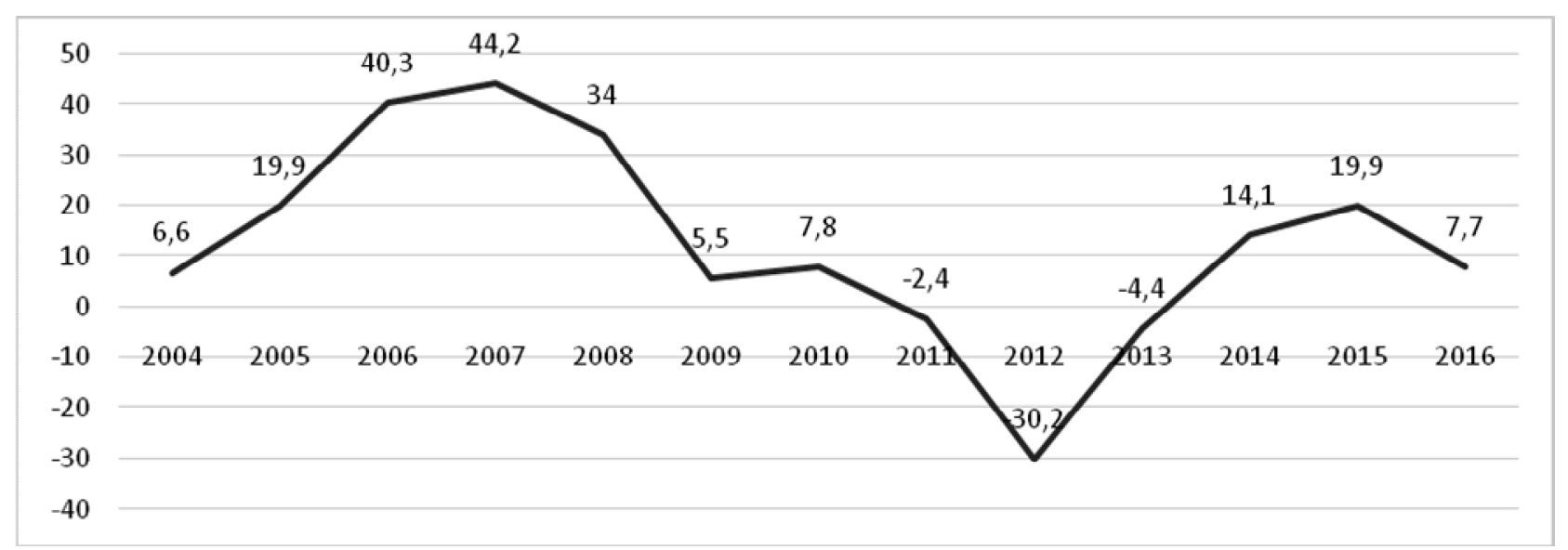

Diagram 4. PMR Construction Climate in Poland Index, $3^{\text {rd }}$ quarter $2004-3^{\text {rd }}$ quarter 2016 (data in points)

Explanation: The value of the index for July 2014 is calculated based on five variables and does not allow for the estimate of the order portfolio. The index is theoretically delimited by values -100 (extremely bad climate) to +100 (ideal condition of the construction market). In practice, the index values may fluctuate within the range of -60 to +60 . In case the index is above 50 , the market situation may be considered to be very good, whereas value -50 is indicative of a very bad situation. The index is based on the estimate and predictions of big construction companies regarding their own financial situation as well as the situation on the market as a whole.

For August 2016, opinions of 114 respondents were taken into consideration. The mean values for the specific questions constituting the index were calculated except areas where no data were available.

Source: [11, p. 56]

The value of the Construction Climate Index in September 2016 was 7.7 points, which, compared with the $3^{\text {rd }}$ quarter of 2015 (19.9 points), indicates bearish economic mood. The Index value in September 2016 is comparable to the values of 2010 and marks a change of trends in comparison to those in 2014 and 2015. It should be pointed out that given the methodology assumed by PMR, the value of the index discussed here was worse in all the three segments of the construction market, i.e., residential housing, non-residential construction and engineer construction. The falls were noted both with respect to 2015 and 2014.The detailed data are represented in Diagram 5.

The analysis of Diagrams 4 and 5 indicates the beginning of falls of the Construction Climate Index. It is hard to predict whether this tendency will continue or whether, as the PMR analysts suggest, it is a "transitional technical correction" which is going to change with the inflow of the EU funds related to planned, yet delayed investments [11, p. 56]. 


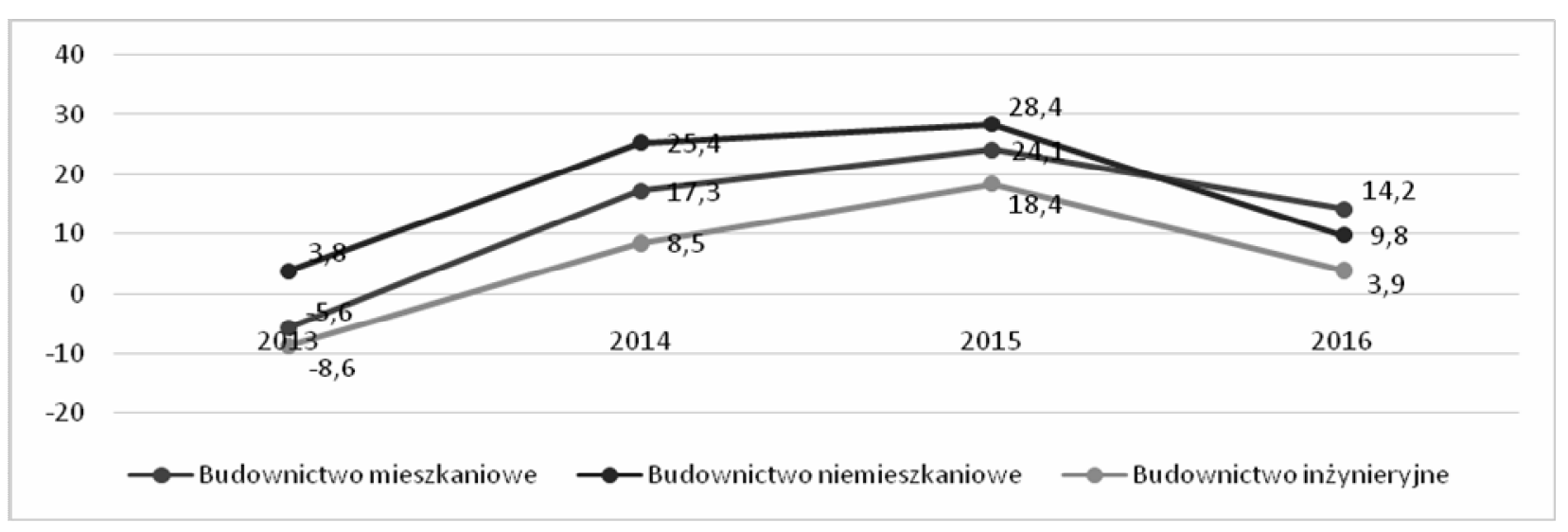

Diagram 5. PMR Construction Climate Index in Poland, $3^{\text {rd }}$ quarter
of $2013-3^{\text {rd }}$ quarter of 2016, divided into segments of construction market (data in points)

Source: $[11$, p. 56]

\section{research}

Conclusions and perspectives for further

According to the analysts of the Market Research and Analysis Centre (CBiAR), the falls noted in the first three quarters of 2016 will not be made up for given the delays (also mentioned here). Unless the market situation changes, one can expect the improvement of the economic conditions on the construction market no earlier than in 2018. Yet another factor pointed out by analysts is the increase of prices of building materials, which may drive a number of companies taking part in tenders bankrupt should they overlook this aspect in their tender bids. The CBiAR analysts also indicate that the reliability of the forecasts of the development of the economic conditions of the construction market in Poland is further affected by the domestic economic and political situation. Finally, they point out that any potential rise in the value of the indicators in 2017 will rather be the consequence of the lowering of the reference base for 2016 [10, p. 65].

Further study of the development tendencies of the economic conditions of the construction market should focus on the level of implementation of the objectives of sustainable construction, realisation of government initiatives in the sphere of residential housing as well as long-term analysis of the residential needs in Poland in comparison to the standards noted in other EU member states.

\section{References}

1. Czarnecki L., Kaproń M. (2012) Budownictwo przyszłości 三 zrównoważone budownictwo /
L. Czarnecki, M.Kaproń// Materiały Budowlane. 2012. - No. 1.

2. Czarnecki L., Paszkowski Z. (2015) Utrzymanie budynków $i$ rewitalizacja obszarów miejskich zgodnie z zasadami zrównoważonego rozwoju / L.Czarnecki, Z. Paszkowski // XXX Jubileuszowe Ogólnopolskie Warsztaty Projektanta KonstrukcjiSzczyrk.-2015.

3. Piasecki M. (2010) Metoda oceny budynku pod katem zrównoważonego rozwoju / M. Piasecki // Materiały Budowlane - 2010. - No. 5.

4. Pabian A. (2012) Budowlany proces inwestycyjny $w$ koncepcji sustainability / A. Pabian // Przeglad Budowlany - 2012. - No. 10.

5. Kowalska M. (2016) Efekty budownictwa mieszkaniowego w 2015 r. / M. Kowalska // Materiaty budowlane - 2016. - No. 2.

6. Ruch budowlany w 2015 roku (2016) Informator Glównego Urzędu Nadzoru Budowlanego Materiały Budowlane - 2016. - No. 4.

7. Wielgo M. (2016) Co się dzieje z budownictwem? / M. Wielgo // [Electronic resource]. - Access mode: http://www.inzynierbudownictwa.pl/wydarzenia,o_ tym_sie_mowi,artykul,co_sie_dzieje_z_budownictw em_,9138

8. Kwiatkowska M. (2016) Rekordowe budowy / M. Kwiatkowska // Dziennik Gazeta Prawna 27.09.2016. - No. 187. (4334).

9. Kobylarz J. (2016) Sprzedaż produkcji budowlanomontażowej i produkcja sprzedana budownictwa $w$ okresie trzech kwartałów 2016 roku /J. Kobylarz, // Materiały Budowlane - 2016. - No. 11.

10. Tomczak B. (2016) Rok 2017 - wyzwanie dla branży budowlanej? / B. Tomczak // Builder 2016. - No. 12. (233).

11. Sosna B. (2016) Rok dobrych prognoz / B. Sosna // Builder-2016. - No. 12. (233). 